\title{
Socio-Cultural Practices Harmful on Female Reproductive Health: A Case Against Female Genital Mutilation
}

\author{
Vivian Chukwudumebi Madu \\ Nigerian Institute of Advanced Legal Studies, University of Lagos Campus, Akoka Lagos. Nigeria
}

\begin{abstract}
About 115 to 130 million girls and young women have experienced $\mathrm{FGM} / \mathrm{C}$, otherwise referred to as Female Genital Mutilation/cutting and an additional three million are at risk each year. It is one of the most political areas of women's health. The practice of FGM/C harms the physical, psychological, reproductive and sexual health of women and is a violation of women's fundamental human rights. The federal government of Nigeria in 2015 enacted the Violence against Person's Prohibition Act which made provisions criminalising FGM. However the VAPP Act is only applicable in the Federal Capital Territory because it is a matter provided for under the concurrent legislative list. Hence, other states of the federation are expected to pass the same law to become applicable within their states. The main objective of this study is to ascertain, the extent to which FGM is harmful to female reproductive health and ascertain the effectiveness of the VAPP Act, the Constitution and other health policies of government in the eradication of FGM. Despite the VAPP Act which criminalised the offence of FGM there is still a high level of ignorance amongst practitioners. Apart from the violation of the right against torture and the dignity of the human person the study found that there are other dangers associated with the practice varying from danger to physical health resulting from unhygienic and unskilled procedures. Other lifelong effects can result in infertility, since the procedure can limit sexuality and childbearing capacity.
\end{abstract}

Keywords: Female Genital Mutilation, Reproductive Health

DOI: $10.7176 / \mathrm{JLPG} / 100-07$

Publication date:August $31^{\text {st }} 2020$

\subsection{Introduction}

Female Genital Mutilation (FGM) is an unhealthy traditional practice inflicted on girls and women worldwide. Worldwide it is estimated that well over 130 million women have been subjected to FGM (Ladan Furgan, 2019). FGM is widely recognized as a violation of human rights, which is deeply rooted in cultural beliefs and perceptions over decades and generations with no easy task for change. Supporters of this practice consider it as an important part of cultural and religious life, and some compare it to the practice of male circumcision that is more widely accepted world over, however opponents contend that it is not only potentially life threatening, but also an extreme form of oppression of women (Ladan Furgan, et al 2019). Contrasting FGM with male circumcision which is the surgical removal of the foreskin, the tissue covering the head (glans) of the penis. It is an ancient practice that has its origin in religious rites. Today, many parents have their sons circumcised for religious or other reasons. It is usually performed on the first or second day after birth. Among the Jewish population, circumcision is performed on the eighth day (WHO, 2017). The procedure becomes more complicated and riskier in older babies, children, and men. During a circumcision, the foreskin is freed from the head of the penis, and the excess foreskin is clipped off. If done in the new born period, the procedure takes about five to 10 minutes. It is medically believed to help prevent penile cancer and a reduced risk of cervical cancer in female sex partners. Prevention of balanitis (inflammation of the glans) and balanoposthitis (inflammation of the glans and foreskin). Prevention of phimosis (the inability to retract the foreskin) and paraphimosis (the inability to return the foreskin to its original location) (WHO, 2018).

There is compelling evidence that male circumcision reduces the risk of heterosexually acquired HIV infection in men by approximately $60 \%$. Three randomized controlled trials have shown that male circumcision provided by trained health professionals in properly equipped settings is safe. WHO/UNAIDS recommendations emphasize that male circumcision should be considered an efficacious intervention for HIV prevention in countries and regions with heterosexual epidemics, high HIV and low male circumcision prevalence (WHO, 2018). Now looking at the health benefits of a male circumcision one cannot say the same of FGM. Rather medical evidence abound that a lot of women who suffer tear and bleeding during child birth is as a result of FGM conducted on them (WHO, 2017).

In Nigeria, subjection of girls and women to obscure traditional practices is legendary (Okeke, Ayaehie \& Ezenyeaku, 2004). In some other African countries where FGM is more widely practised like Senegal it is officially illegal and anyone found guilty of the practice faces a prison term of between one and five years ( Okeke, Ayaehie \& Ezenyeaku, et al 2004). Nigeria taking a lead from other jurisdiction passed the Violence Against Persons Prohibition Act (VAPP Act) in 2015 criminalising the practice of FGM. Although FGM is practiced in more than 28 countries in Africa and a few European communities, its burden is seen more in Nigeria, Egypt, Mali, Eritrea, Sudan, Central African Republic and northern part of Ghana where it has an old traditional and cultural practice 
of various ethnic groups (Okeke, Ayaehie \& Ezenyeaku, et al 2004).Outside Africa, FGM is mainly carried out in western and southern Asia and the Middle East (Ladan 1999). It is known to take place among immigrants communities in the United States of America, Canada, France, Australia and Britain. It is estimated that over 20,000 girls under the ages of 15 are at risk of FGM each year in the United Kingdom and 66,000 women in the UK are living with the consequences of FGM (Okeke, Ayaehie \& Ezenyeaku, et al 2004). In countries were FGM have been criminalised parents who are adamant on the practice take their children back to their home country during their summer vacation allowing them time to heal before they return back to school. There are worries that some girls may have FGM performed against them secretly in their homes in the UK (Ladan 1999).

The practice is an ethnic marker, rooted in gender inequality, ideas about purity, modesty and aesthetics, and attempts to control women's sexuality James 2008. In every society in which FGM is practiced, it is seen as a manifestation of gender inequality that is deeply entrenched in social, economic and political structures. FGM is recognised internally as a violation of the human rights of girls and women. It reflects deep rooted inequality between the sexes, and constitutes an extreme form of discrimination against women (Nussbaum 1999). It is supported by both women and men in countries that practice it, particularly by the women, who see it as a source of honour and authority, and an essential part of raising a daughter well (Mackie \& Lejeune 2008). It is widely believed that by mutilating the female genitalia, a woman's sexuality is curtailed. This harmful practice often forms an important part of the customary rites of passage of young girls into adulthood (Aniekwu 2011). Most sympathetic is that in communities where it is practiced, the female folks have been psychologically tortured to accept it as normal. In fact, under this psychological belief, a woman is not seen to be complete if she has not been circumcised. She is considered unclean and unfit for marriage, hence the phenomenon that lead to some young girls cutting themselves so that men from their communities could marry them. Worse still the female folk have been made to believe and accept that cutting off of the clitoris makes the female genital organ more beautiful and appealing. The Women's Centre for Peace and Development (WOPED) (Mackie \& Lejeune 2008)has concluded that Nigerians continue this practice out of adherence to cultural dictate's that uncircumcised women are promiscuous, unclean, unmarriageable, physically undesirable and/or potential health risks to themselves and their children, especially during childbirth. One traditional belief is that if a male child's head touches the clitoris during child birth, the child will die (Akande 1999). This of course is not supported by any medical evidence. Indeed, were it true, no live-births of male children would have been recorded for mothers who have not been mutilated. On the contrary, there is ample evidence to show that there are many health hazards for women who have been subjected to the humiliation of the practice.

There is the risk of infection from the use of unsterilized implements used for the operation. Excessive blood loss during child birth and subsequently vesico vagina fistulae (VVF) which results from obstructed labour, or infertility from infection of the reproductive tract. Amongst these risk the victim suffers psychological and emotional shock. Putting the fore goings together it is contended that whatever benefits, if any, the disadvantages far outweigh the advantages (Ladan \& Furgan 2019).

This study is divided into three main parts namely the introductory perceptive which covers the introduction and conceptual clarifications. The second part explores the barriers to reproductive health within the Nigerian society such as FGM which are mainly socio-cultural. It highlights legal and policy initiatives adopted to address this problem such as the Violence against Persons Prohibition Act, various State legislations and the Constitution of the Federal Republic of Nigeria. It concludes with recommendations towards effective implementation of reproductive health rights policy, eradication of harmful socio-cultural practices such as FGM by enforcing both State and national legislation, while emphasizing awareness campaign.

\subsection{Conceptual Clarifications}

\subsection{Female Genital Mutilation}

It can be defined as "partial or total removal of the external female genitalia or other injury to the female genital organs for non-medical reasons" (Usman 2000). Female genital mutilation (FGM) is defined by the World Health Organization (WHO, 1998) as "all procedures which involve partial or total removal of the external female genitalia and/or injury to the female genital organs, whether for cultural or any other non-therapeutic reasons." Akande (1999) defines FGM as "the removal of the clitoris sometimes with adjacent parts of the labia majora." Others define Female Genital Mutilation as "a destructive operation, during which the female genitals are partly or entirely removed or injured with the goals of inhibiting a woman's sexual feelings." Stanlie 2008. According to Elneil(2016) the procedure is carried out in remote areas as well as in cities and at all levels of the society weather rich or poor. Momoh (2004) describes the procedure as being carried in rural villages by older women known as traditional cutters or birth attendants. Who carry out the procedure with crude instruments such as knives, razors, scissors or sharp stones. Most unfortunate is that the same instrument is used to cut several girls at the same time under unhygienic conditions.

The practice of female genital mutilation/cutting (FGM/C) harms the physical, psychological, reproductive and sexual health of women and it is a violation of women's fundamental human rights. As Gloria (2019) puts it, 
people are mostly concerned about the physical/medical harms without referring to the social and psychological effect of such terrible crime. FGM is basically done to females to suppress their sexual desire and dominate them. It is great psychological trauma for a teenage girl or woman to be tied up by family members for the purpose of being cut. Worst still is when she has to under-go this humiliation and trauma as a condition precedent to marriage. The resulting psychological effect is that such a girl will feel easily dominated and inferior to her male counterparts for the rest of her life. Especially when she compares herself with her male siblings who did not have to undergo such humiliation as teenage boys. Circumcision of boys usually happen very early in life and it is celebrated by the family and neighbourhood. FGM is done secretly and it is meant to be an" immunity" against sexual desire and "sin". It is equally believed that FGM would make the girl remain a virgin. As Varol (2014) puts it, the continued practice of FGM is motivated by peer pressure and the desire to be seen as marri able by the male forks. It is also meant to keep the girl's natural urge of sexual satisfaction in check or even responsiveness after marriage, turning her into a reproduction machine. For Kaplan \& Martins (2011) FGM is practiced to enhance men's sexual pleasure. In such culture, men take over by the power of the community and women lose their self-esteem. On another perspective Mohamud \& Yinger (1999) suggests that the practice of FGM is required for both spiritual and religious cleanliness. It is Gloria's (1980) opinion that victims are likely to have psychiatric disorders, anxiety, somatisation (the production of recurrent and multiple medical symptoms with no discernible organic cause), phobias, low self-esteem, and depression. Martha (1999) argues that the key moral and legal issue with FGM is that it is conducted on teenage girls using physical force. Obermeyer (1999) argues that FGM may be conducive to women's well-being within their communities in the same way that procedures such as breast implants, rhinoplasty and male circumcision may help people in other cultures.

Austrian-American feminist Fran Hosken (2010) who coined the term Female Genital Mutilation was uncompromising in her criticism, calling FGM a "training ground for male violence" and the women "mentally castrated." She accused the women of "participating in the destruction of their own kind," and argued that infibulation "teaches male children that the most extreme forms of torture and brutality against women and girls is their absolute right and what is expected of real men".

According to Boyle (2002) Clitorectomy is considered one of the rites of passage for young women into adulthood but basically aimed at rendering women sexually subordinate to men since it is claimed that it reduces sexual pleasure and thereby renders women less vulnerable to promiscuity.

\subsubsection{Types of FGM.}

The World Health Organisation (WHO) differentiates four types of Female Genital Mutilation:

1. Excision of the clitoris prepuce ("Sunna-circumcision") and of the clitoris or parts thereof. Type 1.

2. Excision of the clitoris prepuce, the clitoris and the inner lips or parts thereof. Type 2.

Type 1 and 2 are the most common types of FGM: eighty percent of the affected women have gone through these procedures.

3. Excision of part of or all of the external genitals ("infibulation", also referred to as "Pharaonic Circumcision"). Afterwards the remaining parts of the outer lips are sewn together leaving a small hole for urine and menstrual flow. Type 3 .

The scar need to be opened before intercourse or giving birth, which causes additional pain. Infibulation is mainly spread in the Horn of Africa and its neighbouring areas - in Somalia, Djibouti and Eritrea, as well as in the northern part of Sudan and in the southern part of Egypt. It is the most severe form of FGM and affects 15 percent of the women.

4. Pricking, piercing, cutting or stretching of the clitoris or the labia, also burning or scarring the genitals as well as ripping of the vaginal opening or the introduction of corrosive substances or herbs into the vagina in order to tighten it. Plus: any other procedure, which injures or circumcises the female genitalia (Obermeyer 2005). Type 4.

\subsubsection{Criticism of the opposition}

FGM eradicationists, including novelist Alice Walker, have been criticised for failing to respect the women's own desires and interests. Anthropologist Eric Silverman (2004) in his view stated that FGM was one of the central moral topics of contemporary anthropology." Anthropologists have been criticized for adopting a pluralist or relativist stance rather than defending human rights, while the eradicationists stand view FGM as cultural colonialism (Stanlie 2008).

Several anthropologists have challenged the international opposition to FGM, including Shweder, (2007), Boddy, (2000), Obermeyer, (2003) and Ahmadu (2000) who was herself cut as an adult when she was initiated into the Bundu secret society in Sierra Leone. Shweder (2007) argues that anthropologists who specialize in gender issues in Africa have long been aware of the discrepancies between their own experiences and the global discourse on FGM, which in his view has replaced critical thinking with political activism. The accuracy of the factual and moral claims against FGM are taken for granted to such an extent, he argues, that the practice has become an "obvious counterargument to cultural pluralism."Shweder opposes the view of FGM as a human rights violation, arguing that there are no such things as natural rights, but maintains that if a rights perspective is adopted, it must take other rights into account, such as the right to self-determination, autonomy and freedom of religion. He 
highlights the Mandinka of Guinea-Bissau, for whom bodily integrity and purity are required for prayer, and are achieved by circumcision.He argues further that the medical evidence does not support the view of FGM as invariably harmful, citing reviews of the medical literature in 1999, 2003 and 2005 by medical anthropologist and epidemiologist Carla Obermeyer (2003) of Harvard University, who suggested that the more serious medical complications are relatively infrequent.Shweder (2007) also cites a 2001 study by Linda Morison of the London School of Hygiene and Tropical Medicine that looked at the reproductive health consequences of Type II FGM in the Gambia; Morison concluded that there were few differences between the circumcised and uncircumcised women.

\subsubsection{Prevalence of the practice of FGM}

There is another school of thought that view FGM as a tribal traditional practice (our custom is a good tradition and has to be protected), as a superstitious belief practiced for preservation of chastity and purification(Elchalal 1997), family honour, hygiene, aesthetic reasons, protection of virginity and prevention of promiscuity, modification of socio sexual attitudes (countering failure of a woman to attain orgasm), increasing sexual pleasure of husband, enhancing fertility and increasing matrimonial opportunities. Other reasons are to prevent mother and child from dying during childbirth and for legal reasons (one cannot inherit property if not circumcised) (Abdulcadira 2011). In some parts of Nigeria, the cut edges of the external genitalia are smeared with secretions from a snail footpad with the belief that the snail being a slow animal would influence the circumcised girl to "go slow" with sexual activities in future (Yonder 2008). However, FGM is often routinely performed as an integral part of social conformity and in line with community identity (UNICEF, 2013).

The form practiced varies by ethnic group and geographical location. It crosses the numerous population groups and is a part of the many cultures, traditions and customs that exist in Nigeria. It crosses the lines of various religious groups. It is found among Christians, Muslims and Animists alike.

With over 250 ethnic groups and an estimated population of 180 million, a national estimate of this practice is very difficult. The most recent survey is a 1999 Demographic and Health Survey of 8,205 women nationally. This survey estimates that 25.1 percent of the women of Nigeria have undergone one of these procedures.

According to a 1997 WHO study, an estimated 30,625 million women and girls, or about 60 percent of the nation's total female population, have undergone one of these forms. A 1996 United Nations Development Systems study reported a similar number of 32.7 million Nigerian women affected. According to a Nigerian NonGovernmental Organization (NGO) Coalition study, 33 percent of all households practice one of these forms.

However, according to some Nigerian experts in the field, the actual incidence may be much higher than these figures. Leaders of the Nigerian National Committee (also the Inter-African Committee of Nigeria on Harmful Traditional Practices Affecting the Health of Women and Children [IAC]) have been conducting a state by state study of the practice (IWI, 2019).

In 1997 study by the Centre for Gender and Social Policy Studies of Obafemi Awolowo University in Ile-Ife, was contracted by a number of organizations including WHO, the United Nations Children's Fund (UNICEF), the United Nations Development Program (UNDP), the United Nations Population Fund (UNFPA), the Nigerian Federal Ministry of Women's Affairs and the Nigerian Federal Health Ministry. The study covered 148,000 women and girls from 31 community samples nationwide. The results from fragmented data, according to IAC/Nigeria, show the following prevalence and type in the following states in Nigeria. Abia (no study); Adamawa (60-70 percent, Type IV); Akwa Ibom (65-75 percent, Type II); Anambra (40-60 percent, Type II); Bauchi (50-60 percent, Type IV); Benue (90-100 percent, Type II); Borno (10-90 percent, Types I, III and IV); Cross River (no study); Delta (80-90 percent, Type II); Edo (30-40 percent, Type II); Enugu (no study); Imo (40-50 percent, Type II); Jigawa (60-70 percent, Type IV); Kaduna (50-70 percent, Type IV); Katsina (no study); Kano (no study); Kebbi (90-100 percent, Type IV); Kogi (one percent, Type IV); Kwara (60-70 percent, Types I and II); Lagos (2030 percent, Type I); Niger (no study); Ogun (35-45 percent, Types I and II); Ondo (90-98 percent, Type II); Osun (80-90 percent, Type I); Oyo (60-70 percent, Type I); Plateau (30-90 percent, Types I and IV); Rivers (60-70 percent, Types I and II); Sokoto (no study); Taraba (no study); Yobe (0-1 percent, Type IV); FCT Abuja (no study) (Okeke, Ayaehie \& Ezenyeaku, et al 2004).

While all three forms occur throughout the country, Type III, the most severe form, has a higher incidence in the northern states. Type II and Type I are more predominant in the south. Of the six largest ethnic groups, the Yoruba, Hausa, Fulani, Ibo, Ijaw and Kanuri, only the Fulani do not practice any form. The Yoruba practice mainly Type II and Type I. The Hausa and Kanuri practice Type III. The Ibo and Ijaw, depending upon the local community, practice any one of the three forms.

\subsection{Reproductive Health}

Reproduction is the process of bringing a young one into life. Therefore reproductive health concerns all the activities before conception through gestation and delivery. It is important for the female body which carries the embryo to be healthy as anything that affects the birth channel can invariably affect the health and life of the carrier i.e the female. Reproductive health include sexual health. It refers to a state of complete physical, mental and social 
well-being and not merely the absence of disease or infirmity in all matters relating to the reproductive system and to its functions and processes (Fagbohungbe, 2012). While it is difficult to express a comprehensive agreed definition, major components of reproductive and sexual health and rights include reproductive decision making, equality and equity for women and men, and sexual and reproductive security (Obermeyer 2003). Reproductive security relates to protection from all forms of gender-based violence such as FGM, sexual harassment, marital violence and rape as well as physical and emotional security.

Protocol on the Right of Women in Africa is one of the key instruments for advancing reproductive and sexual health rights in Nigeria. The policy on women provides that government shall make mandatory provisions of maternal health services to all women to protect them against disabilities such as Vesico Vaginal Fistula (VVF), FGM and other harmful traditional practices (Ladan 2006). However the policy on women is vague, about practices such as FGM, referring to the elimination of harmful traditional practices that affect the health of girls and women is not sufficient without stipulating punishment.

Domestically, the 1999 Nigeria Constitution being the supreme law of the land contains provisions under sections 17 and 33 to 45 that are relevant for the promotion and protection of reproductive health and rights in Nigeria. In addition, section 54 of the Nigerian labour Law, Chapter 21 and Part 5 of the Criminal Code, and sections 18 of the Marriage Act as well as 3 of the Matrimonial Causes Act, contain relevant but controversial provisions relating to reproductive health and rights. Further, there are equally relevant State legislation on the prohibition of various forms of discrimination and violence against women and the girl-child.

Furthermore, the provisions of the National Reproductive Health Policy and Strategy of 2001, the National policy on HIV/AIDS, 2003, the National Policy Health Policy and Strategy, 1998 and 2004, National Policy on Women, 2000 and 2004, National Policy on the Elimination of Female Genital Mutilation, 1998 and 2002, the National Adolescent Health Policy, 1995, National Policy on Maternal and Child Health, 1994, and the National Policy on Population for Development, Unity, Progress and Self-reliance, 1988 and 2004, constitute the key policy frameworks that seek to achieve quality reproductive and sexual health for all Nigerians.

Moreover, there are two broad components of the sources of international instruments relevant to reproductive health and rights (Ladan 2006). These are: - a) Legally binding instruments and, b) non-binding standards/instruments on Nigeria.

In addition to the above Protocol, women's reproductive and sexual health rights, including the rights to equality, life, liberty, security of the person, health, family planning, consent to marriage, privacy, protection from all forms of discrimination, sexual violence, harmful practices, and from cruel, inhuman, and degrading treatment or punishment, are embedded in the following African and UN international human rights treaties ratified by Nigeria.

1. The African Charter on Human and Peoples' Rights (Articles 3-6, 16).

2. The OAU Charter on the Rights and Welfare of the African Child (Articles 3-16).

3. UN Convention on the Rights of the Child (CRC) (Articles 1, 6, 16, 24, 37, 19, 34),

4. UN Convention on the Elimination of All Forms of Discrimination against Women (CEDAW) (Articles 1, $2,5,6,10-12,16)$.

5. International Covenant on Economic, Social and Cultural Rights (ICESCR) (Articles 2, 10, 12-13).

6. International Covenant on Civil and Political Rights (ICCPR) (Articles 6, 7, 9, 17, 23).

7. UN convention Against Torture (CAT) (Article 1).

8. UN Convention on the Elimination of All Forms of Racial Discrimination (Article 5).

These treaties are legally binding instruments that require all ratifying countries (like Nigeria) to take specific actions at the national level to respect, promote and protect reproductive and sexual health rights of women in particular.

Of all the above mentioned treaties, only the African Charter on Human and Peoples' Rights had been domesticated as Cap, 10 Laws of the Federation of Nigeria, 1990 and applied in cases that came before Nigerian courts. However this charter contains the following key shortcomings as it pertains to women: -

a) its failure to explicitly define discrimination against women

b) its lack of guarantee to the right to consent to marriage and equality in marriage; and,

c) its emphasis on traditional values and practices that have long impeded the advancement of women's rights in Africa.

Another bold attempt to implement the provisions of the UN Convention on the Rights of the Child (CRC) and African Charter on the Rights and Welfare of the Child, as well as CEDAW in particular, are the following Nigerian Laws at both the Federal and State levels: -

The Child Rights Act, 2003: - defines a child as a person below the age of 18 years; and sets 18 as the minimum legal age for all purposes, including marriage, sexual consent, criminal liability, deprivation of liberty, corporal punishment and imprisonment, as well as subjecting to capital punishment, labour, economic and sexual exploitation; etc (Section 277, 21-34 and 221). It however failed to protect the girl-child from harmful practice like FGM. 


\subsubsection{Health Hazards}

FGM has no health benefits, and it harms girls and women in many ways. It involves removing and damaging healthy and normal female genital tissue, and interferes with the natural functions of girls' and women's bodies (Elneil 2016).

The practice involves one or more of several procedures, which vary according to the ethnic group. They include removal of all or part of the clitoris and clitoral hood; all or part of the clitoris and inner labia; and in its most severe form (infibulation) all or part of the inner and outer labia and the closure of the vagina. In this last procedure, which the World Health Organisation calls Type 111 FGM, a small hole is left for the passage of urine and menstrual blood, and the vagina is later opened up for intercourse and childbirth also (Elchalal 1997). The procedures are generally performed, with or without anaesthesia, by a traditional circumciser (a cutter or exciseuse), usually an older woman who also acts as the local midwife, or daya in Egypt (Hadi \& Amal 2000). FGM are often conducted inside the girl's family home (UNICEF 2003). They may also be performed by the local male barber, who assumes the role of health worker in some areas (UNICEF 2006). Medical personnel's are usually not involved, although available data show that in Egypt, Sudan and Kenya health professionals are involved in the surgical process of female circumcision which is often times performed in people's homes. (UNICEF 2013).In some communities it is performed on pregnant women during the birthing process and accounts for much of the high morbidity and mortality rates.

When traditional circumcisers are involved, non-sterile cutting devices are likely to be used, including knives, razors, scissors, cut glass, sharpened rocks and fingernails. Cauterization is used in parts of Ethiopia (Kelly, Hillard\& Adams 2005). The practice under traditional setting is that a circumciser would use one knife to cut up to 30 girls at a time (Wakabi 2007). This unimaginably increases the risk of transferring deadly diseases like the Acquired Immune Deficiency Syndrome (Aids) and hyperthetisis. With Type III the wound may be sutured with surgical thread, or held closed with agava or acacia thorns. Depending on the involvement of healthcare professionals, any of the procedures may be conducted with a local or general anaesthetic, or with neither. The most recent data for Egypt, where medical personnel often carry out the procedure, showed that in 60 percent of cases a local anaesthetic was used, in 13 percent a general, and in 25 percent none (UNICEF 2013).

The health effects depend on the procedure but can include recurrent infections. Adverse consequences of FGM are shock from pain and haemorrhage (WHO 2008), infection, acute urinary retention following such trauma, damage to the urethra or anus in the struggle of the victim during the procedure making the extent of the operation dictated in many cases by chance,(UNICEF 2013) chronic pelvic infection, tetanus or sepsis (bacterial infection), acquired gynatresia resulting in hematocolpos, vulval adhesions, dysmenorrhea, retention cysts, and sexual difficulties with anorgasmia. Other complications are implantation dermoid cysts and keloids, (Yonder 2008) and sexual dysfunction.

Obstetric complications include perineal lacerations and inevitable need for episiotomy in infibulated parturient. Others are defibulation with bleeding (Abdulcadira, Margairaz, Boulvain \& Irion 2011) injury to urethra and bladder, injury to rectum, and puerperal sepsis. Prolonged labour, delayed $2^{\text {nd }}$ stage and obstructed labour leading to fistulae formation, and increased prenatal morbidity and mortality have been associated with FGM (Silverman 2004). Equally associated with FGM is an increased risk of childbirth complications and new born deaths and the need for later surgeries. For example, the FGM procedure that seals or narrows a vaginal opening (Type 3 above) needs to be cut open later to allow for sexual intercourse and childbirth. Sometimes it is stitched again several times, including after childbirth, hence the woman goes through repeated opening and closing procedures, further increasing immediate and long-term risks (UNICEF 2013).

The mental and psychological agony attached with FGM is deemed the most serious complication because the problem does not manifest outwardly for help to be offered. The young girl is in constant fear of the procedure and after the ritual she dreads sex because of anticipated pain and dreads childbirth because of complications caused by FGM. Such girls may not complain but end up becoming frigid and withdrawn resulting in marital disharmony (UNICEF 2013).

\subsubsection{Surgical "reversal"}

Surgery can be performed to open up the lower vagina. This is sometimes called "reversal", although it cannot restore sensitive tissue that has been removed. Surgery may be necessary for women who are unable to have intercourse as the vagina is too narrow. In addition, some pregnant women who have had FGM will need to have their lower vagina opened up before labour to allow a safer birth (Obermeyer 1999). Surgery is best performed before pregnancy, or at least within the second trimester of pregnancy (between about 16 and 26 weeks). Some women may be reluctant to undergo reversal until labour starts, because this may be normal practice in their country of origin. The surgery involves making a careful incision along the scar tissue that has closed up the entrance to the vagina, to expose the underlying vagina. (Obermeyer et al 1999).

Adequate pain relief is essential - the procedure is usually performed under local anaesthetic in the outpatient clinic. However, a small number of women will need either a general or spina 1 anaesthetic (injection in the back), which would normally involve a one-day stay in hospital. 
FGM increases the risk of the vagina tearing during delivery, which causes damage and can lead to heavy bleeding. It can also increase the risk of the baby dying during, or just after birth (Okonofua 1996).

\subsection{Legislative framework}

The UN General Assembly voted unanimously to condemn the practice in December 2012, and urged member states to take all necessary steps toward ending it.

The 54 nations of the African group introduced the text of the resolution. (UN General Assembly Resolution 2012). As at 2013, FGM was outlawed in 26 African countries. Outside Africa, FGM is also concentrated in Iraqi Kurdistan, which passed legislation against it in 2012 (UNICEF 2013).As in Europe and the rest of the world, enforcement of the legislation is poor, although there have been arrests in Burkina Faso and Egypt (UNICEF 2013). The Constitution of the Federal Republic of Nigeria (1999) does not specifically refer to violence against women and girls, harmful traditional practices or FGM; Articles 15(2) and 17(2) prohibit discrimination and set out equality of rights respectively, and Article 34(1) provides that every individual is entitled to respect for the dignity of their person and, accordingly, no one 'shall be subject to torture, or to inhuman or degrading treatment (CFRN 1999).'

In 2015 the VAPP Act was passed criminalising the practice of FGM. The VAPP Act aims to eliminate gender-based violence in private and public life by criminalising and setting out the punishment for acts including rape (but not spousal rape), incest, domestic violence, stalking, harmful traditional practices and FGM. Unfortunately this act is only applicable within the federal capital territory. Although some other States have enacted similar legislation however aware of the existence of the law is very low amongst the natives who are involved in the practice of FGM.

\section{1 Right to dignity of human person}

Opponents of this practice relay on the constitution which provides that "no person shall be subjected to torture or inhuman or degrading treatment," as the basis for banning the practice nationwide (Constitution of the Federal Republic of Nigeria (1999).

In the case of Uzoukwu v. Ezeonu, (1991) Part 200, 6 NWLR 708 at 764-778. an Enugu Court of Appeal defined "torture" to include mental harassment, as well as physical brutalization, while inhuman treatment characterizes any act "without feeling for the suffering of the other". Degrading treatment was seen as "the element of lowering the societal status, character, value or position of a person". From the perspective of FGM it means the segregation and stigmatization of persons who did not subject themselves to be cut and possible discrimination against them by their community there by making it impossible for them to marry men from within their community.

When performed on minors and non-consenting women, FGM violates a recognized human right protected in international and regional instruments (Okonofua 1996). Nigeria was one of five countries that sponsored a resolution at the forty-sixth World Health Assembly calling for eradication of harmful traditional practices, including FGM/FGC.

A number of National Policy to protect the health of women has been promulgated (National Policy on Elimination of Female Genital Mutilation (1998). Several states in the country have enacted specific laws on women's health and gender issues Enugu State; the Female circumcision and Genital Mutilation (Prohibition) Law (2000). Although there are differences between policy and practice, these laws nevertheless indicate state commitment to protect women's health. Female Genital Mutilation has been outlawed in more than 19 states including Cross River, Akwa Ibom, Delta, Edo, Osun, Rivers, Bayelsa and Ogun, covering strategic areas of the country where this practice is prevalent and widespread. Edo State banned this practice in October 1999. Persons convicted under the law are subject to a 1000 Naira (US\$10) fine and imprisonment of six months. While opponents of the practice applaud laws like this as a step in the right direction, they have criticized the small fine and lack of enforcement so far.

At the time of writing, the VAPP Act the Child rights Act has not yet been implemented across all states of Nigeria and only 13 (mainly southern) states had put in place some form of law banning FGM. In some northern areas of the country, the Sharia Penal Codes of states including Zamfara, Kano Kebbi, Kaduna and Sokoto are in place to protect children against various forms of physical and psychological violence.

The VAPP Act does not provide a clear definition of FGM; Section 6(1) of the law opens with the simple statement, 'The circumcision or genital mutilation of the girl child or woman is hereby prohibited.'

Section 6(2) criminalises and punishes anyone who performs, or engages another to perform, female circumcision or genital mutilation.

Section 6(3) criminalises and punishes anyone who attempts to perform, or engage another to perform, the practice.

Finally, Section 6(4) criminalises and punishes those who incite, aid, abet or counsel another to perform or attempt to perform FGM. 
The VAPP Act does not expressly criminalise failure to report FGM that has taken place or is due to take place.

Harmful practices that risk the spread of HIV (for example, through unclean instruments used by traditional FGM practitioners) are also addressed in the, HIV and AIDS (Anti-Discrimination) Act, 2014, under Section 3(3), which states, 'No culture, practice or tradition shall encourage practices that expose people to the risk of HIV infection.'

\subsection{Medicalised FGM}

According to the most recent Nigeria Demographic and Health Survey (2013), 11.9\% of girls aged 0- 14 and $12.7 \%$ of women aged 15-49 who have had FGM in Nigeria were cut by a medical professional (mostly by a 'nurse/midwife') (National Population Commission (NPC) [Nigeria] and ICF International (2014).

The VAPP Act does not clearly address FGM carried out by health professionals or in a medical setting; the broad nature of the law, however, would suggest that any member of the medical profession who performs or assists in FGM would also be guilty of a criminal offence and punished accordingly.

Regarding medical malpractice, the Medical and Dental Practitioners (Disciplinary Tribunal) Rules, 2004 (the Medical Act), sets out in Section 16 under 'Penalties for Professional Misconduct' that, where a registered person (i.e. a medical practitioner) is found guilty of professional misconduct by the medical Disciplinary Tribunal or is convicted by any court of law or tribunal for an offence considered incompatible with the status of a medical practitioner, they may be subject to penalties. Although this does not explicitly refer to FGM, if such an action is considered as medical malpractice, it would thus fall under the scope of this law (Medical and Dental Practitioners (Disciplinary Tribunal) Rules (2004). In addition, the National Health Act 2014 under Section 48(1) addresses the removal of tissue, blood or blood product from the body of another living person. The action is liable to prosecution unless it is done with the informed consent of that person, for medical investigations and treatment in emergency cases (where the consent clause may be waived) and in accordance with prescribed protocols by the appropriate authority. Section 48(2) also states, 'A person shall not remove tissue which is not replaceable by natural processes from a person younger than eighteen years.'

\subsection{Cross-Border FGM}

In some countries where FGM has become illegal, the practice has been pushed underground and across borders to avoid prosecution. Nigeria shares borders with other countries where the existence and enforcement of laws varies widely, including Benin, Cameroon and Niger. There is a lack of information on whether the movement across national borders for the purpose of FGM is an issue for Nigeria.

The VAPP Act does not directly address cross-border FGM: it neither criminalises nor punishes FGM carried out on or by Nigerian citizens in other countries.

\subsection{Penalties}

The VAPP Act establishes the following criminal penalties for violation:

1. The performance of FGM or engagement of another to perform FGM carries a punishment of imprisonment not exceeding four years or a fine not exceeding 200,000.00 Naira (US\$554.808), or both.

2. Attempting to perform FGM or engaging another to perform FGM carries a punishment of imprisonment not exceeding two years or to a fine not exceeding 100,000.00 Naira (US\$277.309), or both.

3. Anyone who incites, aids, abets, or counsels another person to perform FGM or engage another to perform FGM is liable on conviction to a term of imprisonment not exceeding two years or to a fine not exceeding $100,000.00$ Naira (US\$277.3010), or both.

Some individual states set out their own penalties for FGM. For example:

Cross Rivers state - The Girl-Child Marriages and Female Circumcision (Prohibition) Law (2000), Section 4 sets out that any person who performs FGM, offers herself for FGM, coerces, entices or induces another to undergo FGM or allows any female who is either a daughter or ward to undergo FGM is liable on conviction to a fine of not less than 10,000 Naira (US\$27.7011) or to imprisonment not exceeding two years for a first offender (and to imprisonment not exceeding three years without an option of fine for each subsequent offence).

Ebonyi state - Following the introduction of the VAPP Act, provided for a five-year prison sentence for anyone who carries out FGM.

Edo state - The Prohibition of Female Genital Mutilation Law (1999) sets out the penalty for performing FGM as not less than three years' imprisonment or a fine of not less than 3,000 Naira (US\$8.3012) or both.

Rivers state - The Child Rights Act (2009), Section 25 sets out that any person who directly or indirectly causes a female child to be subjected to FGM is liable on conviction to a fine not exceeding 50,000 Naira (US\$138.6014) or imprisonment for a term of one year, or both.

In addition:

Punishments for medical malpractice under the Medical Act (2004), Section 16(2) include being struck off the 
relevant professional register or suspension from practice for a period not exceeding six months.

A person who commits an offence regarding the removal of tissue under the National Health Act 2014 will be punished under Section 48(3) (a) with a fine of 1,000,000 Naira (US\$2,77315) or imprisonment of not less than two years, or both.

\subsection{Implementation of the Law}

In response to the passing of the VAPP Act, the National Policy and Plan of Action for the Elimination of FGM/C in Nigeria (2013-2017) was launched under the coordination of the Federal Ministry of Health and the Federal Ministry of Women, Affairs and Social Development.

The National FGM/C Elimination Programme that has been put in place is coordinated by a multi sectoral National Technical Working Group (chaired by the Ministry of Health) and supported by the UNFPA-UNICEF Joint Programme to end FGM (UNJP). Nigeria became part of the UNJP in 2014, partnering with federal ministries and state-level departments in Ebonyi, Ekiti, Imo, Lagos, Osun and Oyo.

There are a wide range of strategies and organisations working to end FGM in Nigeria, including community awareness programmes, health educators, media campaigns and lobbyists for anti-FGM legislation to be fully implemented. State governments have, to date, been slow to respond to the introduction of the VAPP Act and civil society is, in many cases, campaigning hard for state laws to be adopted and/or implemented. Activists have noted that 'there is an inconsistency between the passing and enforcement of laws in Nigeria (Ayodamola 2017).'

The details of anti-FGM legislation are not yet widely known or understood by many, including local police, and the public do not generally have access to the legislation. A recent survey by a local NGO, Society for the Improvement of Rural People (SIRP), among its community in the southern state of Enugu, found that $95 \%$ of respondents had not heard of the VAPP Act. Once the content and meaning of the law was explained to them, over $90 \%$ of respondents felt that the law should be domesticated in their state. Where information is publicly available, it is not always translated into local languages. Anti-FGM projects are also hampered by a lack of enforcement of the law at the local level and the continuing challenge of violence against women across Nigeria. It is noted that the lack of both reported cases of FGM and information-sharing across the country is due to the reluctance of families to report FGM and risk going to court, and the absence of a centralised informationgathering-and reporting system.

Civil society identifies a need for local police and judiciary to be sensitised around the anti-FGM legislation, there are positive signs in some states where laws are in place; for instance, law enforcement agents, including the police, the Nigeria Security and Civil Defence Corps (NSCDC) and Nigeria Immigration Services (NIS), have received training in Osun where FGM prevalence is highest at 76.6\% (National Population Commission (NPC) [Nigeria]). Civil society is concerned that the law is not yet deterring the traditional cutters who rely on FGM to maintain their income and status in the community, and that the law will push the practice underground. It is also suggested that medicalised FGM, which the law does not directly address, is on the increase in Nigeria and there is an urgent need to engage key medical regulatory bodies such as the Nigerian Medical Association. It has not been possible to identify any prosecutions brought under the VAPP Act in Nigeria since its introduction in 2015. The most recent report published by the UNFPA-UNICEF Joint Programme did not list any arrests, cases or convictions for FGM in Nigeria during 2016 (UNFPA-UNICEF 2017).

\subsection{Enforcement of the law against FGM in other jurisdictions}

Canada was the first to recognize FGM as a form of persecution when it granted refugee status in 1994 to Khadra Hassan Farah, who fled Somalia with her 10-year-old daughter to avoid the girl being subjected to it (Farnsworth 1994). As of May 2012 there had been no prosecutions in Canada (Jaffer 2012). There have been several prosecutions in France, where FGM is covered by a provision of the penal code punishing acts of violence against children that result in mutilation or disability (Rahman \& Toubia 2000). There are thought to be up to 30,000 women in France who have experienced FGM, and thousands of girls at risk. Colette Gallard, a French familyplanning counsellor, writes that when it was first encountered there, the initial reaction was that Westerners ought not to intervene, and it took the deaths of two girls in 1982, one of them three months old, for that attitude to change. Between then and 2012 there were 40 trials, resulting in convictions against two practitioners and over 100 parents (Gallard 1995).

There have been no prosecutions in the United Kingdom, where nearly 100,000 girls in England and Wales were thought to be at risk of FGM as of 2007 according to Dorkenoo (Dorkenoo, Morison, \& Macfarlane 2007). The Prohibition of Female Circumcision Act 1985 outlawed the procedure domestically, and the Female Genital Mutilation Act 2003 and Prohibition of Female Genital Mutilation (Scotland) Act 2005 made it an offence to arrange to have it performed outside the UK on British citizens or permanent residents (McVeigh \& Sutton 2010). In June 2013 the British National Society for the Prevention of Cruelty to Children launched a 24-hour national helpline that children at risk can call (Newman 2013).

In the United States, the Centre for Disease Control estimated in 1997 that 168,000 girls living there had 
undergone FGM or were at risk. Fauziya Kasinga, a 19-year-old woman from Togo and member of the TchambaKunsuntu ethnic group, was granted asylum in 1996 after leaving an arranged marriage to escape FGM, setting a precedent in US immigration law (Cullen 1998). Performing FGM on anyone under the age of 18 became illegal in 1997 with the Federal Prohibition of Female Genital Mutilation Act. The Transport for Female Genital Mutilation Act was passed in January 2013 and prohibits knowingly transporting a girl out of the country for the purpose of undergoing FGM (Hassan 2013).Khalid Adem who emigrated from Ethiopia to Atlanta, Georgia, became the first person in the US to be convicted in an FGM case; he was sentenced to ten years in 2006 for having severed his two-year-old daughter's clitoris with a pair of scissors (Hassan et al 2013).

\subsection{Recommendations}

It is evident from the above review of relevant and key national policies and legislations as well as international instruments related to Reproductive Health and Rights in Nigeria, that efforts have been made for the realization of the goals, objectives and targets as set out in the reproductive health policy. However, a lot more needs to be done by exploiting the windows of opportunity that exist in Nigeria. Knowledge of the VAPP law and enforcement is generally weak across Nigeria, and it has not been possible to identify any successful prosecutions to date.

From the identified gaps in the Reproductive Health policies and legislations as well as comments on the level of implementation of the VAPP Act, the following recommendations are made: -

1. A clear definition of FGM in the VAPP Act is needed, which should include all types of FGM, including those specifically practised in Nigeria. The law needs to directly address medicalised FGM and, specifically, criminalise and punish the performance of FGM by health professionals.

2. To improve the policy environment, a vigorous preventive awareness campaign should be mounted like never before. This should be so enriched with cases and statistics to compel a positive change in the behaviour of the target populations and the message should be disseminated consistently and sustainably to the remotest corner of the country. The law could be further strengthened around failure to specifically report knowledge of FGM, whether planned or already taken place. A multidisciplinary approach involving legislation, health care professional organizations, empowerment of the women in the society, and education of the general public at all levels with emphasis on dangers and undesirability of FGM is paramount. Most NGOs working on this issue claim that helping traditional communities change their cultural folklore is necessary to end this practice. Proverbs, songs, theatrical and dance performances and other cultural activities have reinforced this practice for centuries. The NGOs also point out that efforts to end the practice will fail unless Nigerian men learn that uncircumcised women are marriageable, will not be promiscuous and are not poor risks as mothers.

3. To meaningfully enjoy and ensure effective promotion and protection of reproductive health and sexual rights, outlined in the policies, there is the need for urgent constitutional review to upgrade these rights as fundamental human rights under chapter 4 of the constitution or at least, as part of chapter 2 on fundamental objectives and directive principles of state policy. These rights must be made part of constitutional obligations of all levels and tiers of government to respect, observe, promote and protect because they are human rights founded upon principles of human dignity and equality as well as survival issues.

4. The constitutional status of these rights will automatically attract repeal of provisions of anti-reproductive health rights legislations and the adoption of laws that guarantee women and men the full range of reproductive health services; criminal laws that penalize gender-based violence, including violence that occurs in the family, home, in schools and the workplace; laws with education and outreach components, that prohibit FGM; family laws that guarantee women's rights to equality in marriage, including laws that address or recognize women's rights to sexual and reproductive health, prohibition against violence and sexual discrimination/harassment against women. 5. The national response to reproductive health concerns needs to be continuously assessed, to provide all stakeholders with constant feedback on progress with implementation, by identifying actual or potential successes and problems so as to facilitate timely adjustments to implementation. The existing management information system needs to be made more effective by enhancing its capacity (human, technical and financial) with clear statements of measurable objectives in order to serve as an indispensable tool to assess and improve performance. 6. The Federal and State Governments should ensure that adequate funding is available for anti FGM programmes to disseminate clear and accurate information around the law. Laws need to be made accessible to all members of society and easy to understand in all local languages. The provisions of VAPP against FGM could be printed and widely distributed in local languages, to make them more widely available to the public, including in forms that can be used in areas of low literacy. Local community radio and other media channels, including mobile phone technology and social media platforms, should also be considered for dissemination of information on the law in Nigeria. Local police and the judiciary need adequate support and training around the law and should be encouraged to apply sentences provided for by the legislation.

7. The law needs to be adopted consistently across all states as a matter of urgency to ensure interstate movement for FGM does not become a problem if practising communities try to avoid prosecution. In this regard the law also needs to criminalise and punish any movement across national borders for the purpose of FGM. 
8. The increased involvement of local and religious leaders in education around the law, including their responsibilities and the importance of the law in protecting women and girls in their communities, should be encouraged.

9. Effective monitoring and collection of data around enforcement and cases of FGM would help to inform strategies and programmes.

10. Mandatory reporting of instances of FGM by medical staff in hospitals and health centres could be considered. 11. Where they are currently unavailable and a need is identified, appropriate protection measures (for example, emergency telephone lines or safe spaces) should be put in place for girls at risk of FGM.

\subsection{Conclusion}

It is the finding of this study that although government have taken steps through the VAPP Act to criminalise the offence of FGM there is still a high level of ignorance amongst practitioner's and local communities where the practice is predominant. It is equally a finding of this study from available literature that FGM affects many human rights, but it centrally implicates the rights against torture and dignity of the human person and security of the person. FGM can be classified into different types, but even a minor form can implicate and compromise reproductive health, especially when conducted on a minor incapable of providing her own consent due to immature age and family or communal pressure (Ijeoma 2011).Apart from the violation of the right against torture and the dignity of the human person the study equally found there are other dangers associated with the practice varying from danger to physical health resulting from unhygienic and unskilled procedures. Other lifelong effects can result in infertility, since the procedure can limit sexuality and childbearing capacity. Despite awareness campaigns, some women still consent to this harmful practice because of social pressure especially where it is a condition precedent to marriage within a particular local community. Although it is arguable that the liberty and privacy right of a woman can be enforced by the woman to demand that she be circumcised. However, the Political Covenant provides that liberty ought not to be denied except on such grounds and in accordance with such procedures as are established by law (International Covenant on Civil and Political Rights, 1976). In line with international Convention a number of countries have enacted laws to prohibit the practice even by physicians and other health care practitioners, in view of the negative sexual and reproductive health effects of the procedure (Rahman 2003).

As a federal law, the VAPP Act is only effective in the Federal Capital Territory of Abuja, all other states of the federation must pass mirroring laws to enact the legislation and prohibit FGM across the country. The Act criminalises and punishes those who perform, procure, aid and abet the practice of FGM. It should therefore be amended to address failure to report FGM, cross-border FGM or FGM carried out by a medical professional, the law should provide what the consequences and punishment would be. Furthermore it is suggested that prosecutors can still institute legal action against offenders/practitioners of FGM in states where the VAPP Act has not been passed relaying on section 34 of the constitution which prohibits torture, degrading and in human treatment. State parties to the Children's Convention have been urged to take effective steps towards abolishing traditional practices prejudicial to the health of a child (United Nation's Convention on the Rights of the Child 1985). In the same vain the Women Convention urges state parties to the Convention to protect women against harmful practices, and in addition reform cultural practise which endanger women's health (CEDAW 1985). Equally, CEDAW's recommendation on Female Genital Mutilation is that state parties should take effective and appropriate measures towards eradicating the practice of FGM (CEDAW 1990).In addition to international Convention's State have the obligation to prevent the practice by prohibiting health professionals, local birth attendants and any other group of persons involved in the practice from continuing in the practice.

The Political Covenant in Article 7 further provides that "no one shall be subjected to torture or to cruel, in human or degrading treatment or punishment. In particular, no one shall be subjected without his free consent to medical or scientific experimentation"(International Covenant on Civil and Political Rights, 1993). The traditional application of the right to be free from torture and from cruel, inhuman and degrading treatment was initially only to ensure that prisoners are treated in humane ways. Courts and human rights tribunals are now moving beyond this, to ensure that the inherent dignity of a person is respected, protected, and fulfilled.

\section{References}

Abdulcadira, Jasmine; Margairaz, C.; Boulvain, M; Irion, O; (2011) "Care of Women with Female Genital Mutilation/Cutting" Swiss Medical Weekly, 6(14).

Ahmadu Fuambai, (2000) Rites and Wrongs: An Insider/Outsider Reflects on Power and Excision, in ShellDuncan and Hernlund, p. 283.

Ayodamola Owoseye (2017) 'Why Nigerian government must enforce laws against female genital mutilation Expert', Premium Times, 16 November. Available at https://www.premiumtimesng.com/news/morenews/249572nigerian-govt-must-enforce-laws-female-genital-mutilation-expert.html

Boyle, Elizabeth Heger.(2002) Female Genital Cutting: Cultural Conflict in the Global Community, Johns 
Hopkins University Press, p. 25

Constitution of the Federal Republic of Nigeria

Available

at http://www.icnl.org/research/library/files/Nigeria/constitution2.pdf

Convention on the Elimination of all forms of Discrimination against Women (CEDAW) opened for signature Dec. 18, 1979, art. 12(1), 1249 U.N.T.S. 13, 19 I.L.M.33 (entry into force Sept 3, 1981) rectified on the $13^{\text {th }}$ of July 1985.

Cross River State law on Girl Child Marriage and Female Circumcision (Prohibition) law.

Cullen-DuPont, Kathryn. "Female genital mutilation," Encyclopedia of Women's History in America, Da Capo Press, 1998, p. 85.

Dorkenoo Efua, Morison Linda, and Macfarlane Alison, A (2007) Statistical Study to Estimate the Prevalence of Female Genital Mutilation in England and Wales, (Forward, October 2007), p. 25.

Ebonyi State law on the Abolition of Harmful Traditional Practices against Women and Children 2000,

Edo state law on Female Genital Mutilation (Prohibition) Law 1999.

Elchalal Uriel, (1997) Ritualistic Female Genital Mutilation: Current Status and Future Outlook, Obstetrical \& Gynecological Survey, 52(10), October 1997, pp. 643-651

El Hadi, Amal Abd. (2000) "Female Genital Mutilation in Egypt" in Meredeth Turshen (ed.), African Women's Health, Africa World Press, p. 148: "In the main dayas (female traditional birth attendants) and barbers (male traditional health workers) perform the circumcision, particularly in rural areas and popular urban areas." See also www. Unicef-irc.org/publications/2005, p. 7, also http:// www. Unicef.org/media/files,2013, pp.42-44

Elneil S, Female sexual dysfunction in female genital mutilation. Published in Tropical doctor, 46, (1), 2-11.

Enugu State; the Female circumcision and Genital Mutilation (Prohibition) Law.

Farnsworth Clyde, (1994) Canada gives Somali Mother Refugee Status, The New York Times, 21 July 1994.

Gallard Colette, (1995) Female Genital Mutilation in France, British Medical Journal, 310, 17 June 1995, p. 1592.

Gloria Steinem, (1980) "The International Crime of Genital Mutilation," Ms. Magazine, March 1980, p. 65, $<\mathrm{http}: / /$ www.who.int/mediacentre/factsheets/fs241/en/> accessed on 21 February 2019.

Hassan Yasmeen, (2013) As Global Consensus Accelerates, Obama Strengthens Federal Law Protecting Girls in the Fight Against Female Genital Mutilation, The Huffington Post, 3 January 2013.

HoskenFran, (1979)The Hosken Report: Genital and Sexual Mutilation of Females, Women's International Network, 1979, cited in Johnsdotter and Essen, 2010, p. 31. 1920-2006) - Hosken founded the Women's International Network in 1975 - began researching FGM in 1971 and in 1979 published The Hosken Report: Genital and Sexual Mutilation of Females, coining the term female genital mutilation.

Hill, Amelia, (2013), Female Genital Mutilation Campaigners face death threats and intimidation, The Guardian, 8 May 2013.

Ijeoma Nkolika Aniekwu, (2011) Reproductive Health Law: A Jurisprudential Analysis of Gender Specific Human Rights for the African Region, (Ambik Press ), p. 13.

Imoukhuede N.A, (2016) Judgement of Edo State High Court of Justice, (undated) Female Genital Mutilation (FGM) A Crime in Edo State. Available at http://edojudiciary.gov.ng/wp-content/uploads/2016/10/FemalGenital-Multilation-Fgm-A-Crime-In-Edo-State-By-Hon-Justice-N-A.pdf.

International Covenant on Civil and Political Rights, G.A Res. 2200A (XX1), U.N. GAOR, $21^{\text {st }}$ Sess. Supp. No. 16, at 52, U.N. Doc. A/6316 (1966), 999 U.N.T.S. 171 (entered into force March 23, 1976) (acceded to by Nigeria July 29, 1993) herein after referred to as the Civil and Political Rights Covenant

Jadesola Akande, (1999) Miscellany at Law and Gender Relations, (MIJ Professional Publishers Limited, Lagos, p. 159.

James Stanlie,(2008) Female Genital Mutilation, in Bonnie Smith (ed), The Oxford Encyclopaedia of Women in World History, (Oxford University Press), pp. 259-262.

Jaffer Mobina, (2012) Criminal Code Bill to amend second reading, Debates of the Senate (Hansard), 1st Session, 41st Parliament, 148(79), 15 May 2012.

Jasmine Abdulcadira, and others, (2011) Care of Women with female genital mutilation/cutting, Swiss Medical Weekly, 6(14), January 2011 (review).

Junice Boddy, Rites and Wrongs: (2000) An Insider/Outsider Reflects on Power and Excision, in Shell-Duncan and Hernlund 2000, p. 283.

Kaplan A, Hechavarria S, Martin M, Bonhoure L, (2011) Health consequences of female genital mutilation/cutting in the Gambia, evidence into action, Reproductive health, Vol 8, p. 26.

Kelly Elizabeth, and Hillard, Paula J. Adams, (2005)"Female genital mutilation", Current Opinion in Obstetrics \& Gynecology, 17(5), October 2005, pp. 490-494 (review), p. 491.

Ladan Furgan, Female Genital Mutilation(2019) <http://www.bbc.co.uk/health/physical health/condition/ Shtml $>$ accessed 20 February 2019.

Ladan M.T, (1999) Introduction to International Human Rights and Humanitarian Laws, (A.B.U. Press, Zaria, Nigeria), Chapter 2, p. 28 
Ladan M.T, (2006) Review of Existing Reproductive Health Policies and Legislations in Nigeria, A paper presented at a one - day Stakeholders' forum on Reproductive Health in Nigeria. Organized by the Independent Policy group, Abuja. 2Oth April, 2006

Mackie Gerry and Lejeune John, (2008) Social Dynamics of Abandonment of Harmful Practices: A New Look at the Theory, (UNICEF Innocenti Research Centre), pp. 6-7.

Mandara Mairo Usman, (2000) Female genital cutting in Nigeria: View of Nigerian Doctors on the Medicalization Debate (Shell-Duncan and Hernlund) p. 95.

Martha Nussbaum, (1999) Judging Other Cultures: The Case of Genital Mutilation, Sex and Social Justice, Oxford University Press, p. 119.

McVeigh Tracy and Sutton Tara, (2010) British girls undergo horror of genital mutilation despite tough laws, The Guardian, 25 July 2010.

Medical and Dental Practitioners (Disciplinary Tribunal) Rules (2004) Available at http://www.mdcnigeria.org/Downloads/Cap\%20M8.pdf.

Mohamud A.A, Ali N, Yinger N.V, Female genital mutilation: Programmes to Date; What works and what doesn'tA review. Paper presented at Programme for Appropriate technology in health (PATH), 1-7.

Momoh C. Attitudes to female genital mutilation, published in British Journal of Midwifrey, 12(10), p. 631

Mosope Fagbohungbe, (2012) Disability and Reproductive Health in Nigeria in The Rights of Persons with Disabilities Epiphany Azinge and Chinyere Ani (ed.) (Nigerian Institute of Advanced Legal Studies), p. 7.

National Health Act (2014) Available at http://lawnigeria.com/LawsoftheFederation/National-Health-Act,2014.html.

National Policy on Elimination of Female Genital Mutilation (1998, 2002)

National Population Commission (NPC) [Nigeria] and ICF International (2014) Nigeria Demographic and Health Survey 2013, p.357. Available at http://dhsprogram.com/pubs/pdf/FR293/FR293.pdf.

Newman Cathy, (2013) UK's First Female Genital Mutilation helpline finally openly tackles the horrific problem, The Daily Telegraph, 25 June 2013.

Nussbaum Martha, (1999) Judging other Cultures: The case of Genital Mutilation, Sex and Social Justice, (Oxford University Press), p. 124.

Obermeyer Carla,(1999) Female Genital Surgeries: The known and the unknown, Medical Anthropology Quarterly, 31(1), 1999, pp, 79-106

Ogun state the Female circumcision and Genital Mutilation (Prohibition) Law 2000.

Okonofua. F, A (1996) Woman's Right to Health, Including Sexual and Reproductive Health, (Commonwealth Medical Association, London), p. 156.

Okeke T.C and Ayaehie U.S.B and Ezenyeaku C.C.K, An Overview of Female Genital Mutilation in Nigeria, in Annual Medical Health Science Res. 202 Jan-Jun, 2(1), p. 70.

Rahman J(2003) Female Genital Mutilation 29 (Rahman \& Toubia, eds.)

Richard Shweder in Tierney John, (2007) Circumcision or Mutilation and other Questions about a Rite in Africa, The New York Times, 5 October 2007, pp. 217-218.

Silverman Erick K, (2004) Anthropology and Circumcision, Annual Review of Anthropology, 33, 2004, pp. 419445.

"General Assembly Strongly Condemns Widespread, Systematic Human Rights Violations", United Nations General Assembly, 20 December 2012: "[T]he Assembly adopted its first-ever text aimed at ending female

UNICEF (2013), United Nations Children's Fund, Female Genital Mutilation/Cutting: A Statistical Overview and Exploration of the Dynamics of Change, United Nations Children's Fund, July 2013 p. 2.

United Nations, CEDAW (1990) General Recommendation 14 on Female Circumcision, United Nations Human Rights Committee Comment, 108-9, 1990.

UNFPA-UNICEF Joint Programme on Female Genital Mutilation/Cutting (2017) 2016 Annual Report of the UNFPA-UNICEF Joint Programme on Female Genital Mutilation/Cutting: Accelerating Change, p.56. Available https://reliefweb.int/sites/reliefweb.int/files/resources/UNFPA_UNICEF_FGM_16_Report_web.pdf

United Nation's Convention on the Rights of the Child (New York: UNN, 1989), GA Res. 44/25, annex, 44 UN/Gaor. Supp. (No. 49) at 167, UN Doc. A/44/49 (1989), entered into force on $2^{\text {nd }}$ Sept. 1990. 1577, UNTS 3.

United Nation's General Assembly Resolution 2012.

Varol N, Fraser I.S, (2014) Female genital mutilation/cutting towards abandonment of a harmful cultural practice, The Australian and New Zealand journal of obstetrics and gynaecology, 54(5), p. 12206.

Wakabi Wairagala (2007)"Africa battles to make female genital mutilation history", The Lancet, 369 (9567), 31 March 2007, pp. 1069-1070.

World Health Organization, Female Genital Mutilation: An Overview, Geneva, World Health Organization, 1998. WHO (2008), p. 4: "Narrowing of the vaginal orifice with creation of a covering seal by cutting and appositioning the labia minora and/or the labia majora, with or without excision of the clitoris (infibulation)." For the wound 
being opened for intercourse and childbirth,

WHO report on reproductive health (female genital mutilation: An Overview), (2013), p. 4, " Narrowing of the vaginal orifice with creation of a covering seal by cutting and appositioning the labia minora and/or the labia majora, with or without excision of the clitoris (infibulation)." For the wound being opened for intercourse and childbirth.

Yoder Stanley P. and Khan Shane, (2008) Number of Women Circumcised in Africa, United States Agency for International Development, March 2008, p. 14. 